\title{
鉄筋コンクリート土木構造物の耐震性強化のために
}

\author{
岡一本舜
}

わが国に R C 構造物が作られはじめたのは今世紀の初 頭である。それ故に関東大震災（1923 年）は拉そらく それが最初に経験した大地震であろう。関東大震災の際 の東京下町や湘南地方に㧍ける震度はVII と推定され, そこでは建築構造としては工場建築が，土木構造として は橋标や門形橋脚が壊滅的な打撃を受けた。具体的にそ の様子をみると, 工場建築にせよ, 門形橋脚にせよ, 被 害はどちらもはり材に接続する柱の上端部に集中した。 即ち, その部分の被りのコンクリートは剝離し, 内部の コンクリートは塊状に砕け，そのために上部工の重量は 露出した主鉄筋にのみかかり，それを支えか视て鉄筋は くの字型に座屈した。そしてとくに破壊がひどい場合に は, 構造物は安定を失って倒壊した。

関東大震災の際に，東京市の焼跡に残存した建物の被 害を構造種別に調査した結果が同地震の報告書に載って いて（表一1），それを見た時私は R C 建築の被害率が， 石造, れんが造と並んで高いのに驚いた。また福井地震 (1948 年) の際には調查隊に加わって震害を視察し, R $\mathrm{C}$ 造の倉庫や橋桁, 橋脚等の被害が予想以上にひどい事 に気がついた。しかし，これらの $\mathrm{R}$ C構造は $\mathrm{R} \mathrm{C}$ 技術の 黎明期のものであり，これをもって直ちに R C 構造の耐 震に対する弱さを本質的なものと判断するのは問題であ り，やがてこれらの苦い経験を十分に生かして，耐震的

\section{表一1 関東地震による東京市焼跡残存建築物被害統計}

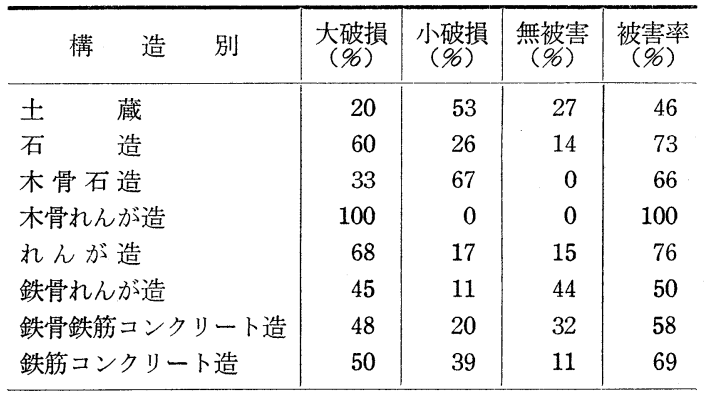

* 前埼玉大学学長
な $\mathrm{R} \mathrm{C}$ 構造を造る技術が確立されるであろうと期待して いた。事実，その後に起きた十勝沖地震（1968 年）で も, 伊豆半島沖地震（1974 年）でも， R C 橋脚につい てこれといら被害が報告されておらず，これは R C 橋り ようの耐震技術の進歩を実証するものと思っていた。

ところが 1978 年 6 月の宮城県沖地震では, R C 橋り ようは道路橋，鉄道橋とも大きな被害を受けた。これは 耐震工学に携わる者にとっては一様に大きなショックで あったとともに，いまだに変ら震害状況をみると現在 の $\mathrm{R} \mathrm{C}$ 構造は, ある限度を超える地震に対しては耐震性 において本質的な欠宿を包蔵しているのではなからうか との䀣念さえもつようになった。

宮城県沖地震によって， R C 橋脚躯体化被害を受けた 主な橋り上うを道路橋について举げると表一2 のようで 西る。この他鉄道橋でも橋脚躯体に同様な被害例があ り，また R C 高架橋においても，ラーメンの中間ばりに せん断ひびわれを生じた事例が多くみられた。眼前にこ のような震害例をみると次のようないくつかの問題を考 えさせられる。

\section{(1) 地震力の評価の問題}

宮城県沖地震では, 多くの橋りょうで振動が記録され た。それによると上部工の応答振動が $500 \mathrm{gal}$ に達した 例もある。従って設計荷重以上の地震力を受けた橋りょ うがかなり多かったように思われる。現行設計震度は， 地震の規模と震央距離と地盤特性とからきめられている が, 震度と規模と震央距離との関係については全国一律 に同じ経験式が使われている。現実には東北地方の東部 地域は, 新潟地震でも震央距離に比して異常に大きな震 度が記録されており, 地震学上は異常震域とされてい る。しかし，こうした特殊事情は現行設計震度決定方式 には採り入れられていない。

また騒音防止への配虑から, 近年コンクリート橋が増 加して橋重が増え, しかも工事着手後に桁上に種々の付 帯構造が追加される事例さえある。このような状況のも とでは，支承及び下部構造には従来よりも厳しい条件が 
課されることになる。一方，計算技術の進歩とともに部 材断面にもこれまでのような曖昧ではあるが何となく存 在したゆとりというものがなくなってしまっている。従 って設計計算の基本となる地震荷重についても, 従来こ れでよかったからという安易な考えは許されず, 正確な 評価が求められる。これらの諸事情が今度の震害の一因 ではないかと考える時, 現行設計荷重の見直しの必要が 感じられる。

\section{（2）動的破壊の実態を明らかにする問題}

コンクリートの静的破壤についての研究の蓄積は多い が，動的破壊，特に R C 部材としての動的破壊について は研究の歴史が浅く, 今後研究をより深める必要がある。 例えば地震力は，水平と上下の 3 方向に同時に作用す るが，この場合における強度はそれぞれの方向に単独に 作用する地震力による強度の単なるベクトル和ではない とされている。また, 繰返し引張圧縮試験において, 塑 性域下では, 荷重繰返し数の増加に伴ってコンクリート はその強度を低下し, 漸次鉄筋が主として引張圧縮を受 けるようになり，遂には鉄筋の座屈現象が起こるとされ ている。こうした荷重の組合せや繰返しだけについて見 ても, 組合せや載荷方法, 荷重履歷等を変えた場合どの ような性質が現れるか，またそれらの性質に及ぼすコン クリートの材質の影響など色々問題がある。更に応用課 題としては, 帯筋等で補剛された時にどんな挙動を示す か等明らかにすべき問題がまだ残っているように思われ る。こうした問題が解明されてはじめて地震許容応力の 決定が合理的に行い得るのであって, 現行の 50\% 割増 しを中心とする許容応力值は当然見直されねばならない 数值である。特にせん断応力についてその感を深くす る。

\section{（3） R C 部材の補強の問題}

破壊状況が明らかになればそれに対する補強が講ぜら
れねばならない。コンクリートの弱点は, 抗張力, 抗せ ん力ともに小さく脆い事であるが，それを鉄筋で補って 粘りを与えるのが R C 構造の特長である。部材が粘りを もつためには, 鋼棒とコンクリートの一体化が不可欠で あり, 両者の付着が重要な要件となる。このために異形 筋, 帯鉄筋, らせん筋, スターラップ等種々の工夫がな されてきたが，まだそうした補強方法と粘りの増加との 関係が解析的にまでは明らかになっていないようであ る。特に内実橋脚のような太い断面の場合, その内部に は配筋されないのが普通で, それで内部コンクリートの 粘りは十分なのであろうか。今度のように橋脚躯体の水 平ひびわれの実例を多く見せられるとそこに疑問が感ぜ られる。

\section{（4） 新材料, 新工法開発の問題}

構造物が地震に耐えるには粘りをもつことが必要なこ とは定説となっているが，コンクリートには粘りがな い。従って，セメントの改良とか鋼繊維の混入とか何ら かの工夫を施してこれに粘りを与える実用化に成功すれ ば， R C 構造の耐震性は一段と向上されるであろう。ま たコンクリートと鋼棒の接着は R C 構造の粘りの基にな っているが，地震のような繰返し外力に対しては接着は 不利な性質である。それで接着によらずして雨者を一体 として㗢かせる方法, 即ち PC工法の主林以外への広い 忘用を開発してはどうであろうか。PC 工法には他の面 で動的荷重に対する弱点があると聞いているが，そうし た面を解決して PC 方式を応用できれば，鉄箭とコン クリートの剝離によっておきる震害は防止されるはずで ある。

以上宮城県沖地震のコンクリート橋の被害をみて感ず るままを述べたが，専門外の者の所見とて当を得ない点 が多いことを恐れている。御教示を賜れば幸いである。

表-2 宮城県沖地震道路橋下部工主要震害

\begin{tabular}{|c|c|c|c|c|}
\hline 橋名 & 総延 長 & 上部 工 & 下 部 工 & 下 部 工 被 害 \\
\hline 千代大橋 & $310 \mathrm{~m}$ & 合成桁 9 連 & $\begin{array}{l}\text { 井筒基礎をもつ RC T型橋 } \\
\text { 脚 }\end{array}$ & 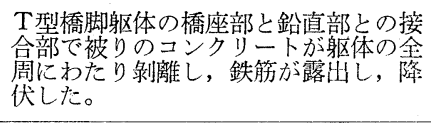 \\
\hline 阿武隈橋 & $571 \mathrm{~m}$ & $\begin{array}{l}\text { 鋼銛桁 } 10 \text { 連 } \\
ワ \text { フ } 7 \text { 連 }\end{array}$ & $\begin{array}{l}\text { 井筒基礎老もつ R C 門形ラ } \\
\text { 一メン橋脚 }\end{array}$ & 橋脚に水平ひびわ扟を生じた。 \\
\hline 䦥上大橋 & $542 \mathrm{~m}$ & 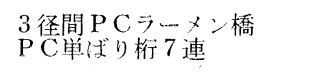 & 井筒基礎定bつ下型橋脚 & 撟脚に水平ひびわれ坣生じた。 \\
\hline 江 台 橋 & $155 \mathrm{~m}$ & 単純鈑桁橋 9 連 & $\begin{array}{l}\text { 2基の独立井简上に R C闒 } \\
\text { 合亏ーメン橋脚をのせる。 }\end{array}$ & 閉合ラーメン橋にひびわれを生したた。 \\
\hline 錦 桜 橋 & $575 \mathrm{~m}$ & $\begin{array}{l}\text { 単純鋼ワーレンートラス } \\
\text { ゲルン゙鈑桁 } 9 \text { 連 }\end{array}$ & 杭基礎門形橋脚 & 槅脚の移動により吊析が落橋した。 \\
\hline
\end{tabular}

